\title{
The Effects of Financial Crisis on Hedging Efficiency of Indian Rubber Future Markets
}

\section{Saji Thazhungal Govindan Nair}

Assistant Professor of Finance; Sri C Achutha Menon Government College, Thrissur, Kerala, India 680014, sajthazhungal@gmail.com

\section{ABSTRACT}

This research, under Engle-Granger Co-integration framework, examines the hedging efficiency of Indian rubber future markets during the period 2004-2017. The essence of this study is to seek evidence for the effects of global financial crisis of 2008 on the efficiency of rubber futures in hedging price risks of spot rubber in India. The study proved the hedging efficiency of rubber futures during both pre and post recession periods. However, increased price volatility of Indian rubber after recession heightened risk exposure to market participants that eventually lead to unexpected changes in the hedging efficiency of rubber futures. The research concludes with a suggestion that writing of rubber futures in India allows traders to hedge risk exposures in spot market along with the potentials of arbitrage gains.

Keywords: Futures; Hedge Ratio; Co-integration

JEL Classification: C58; G01; G17

\section{Introduction}

Free and open market mechanism in the current globalized regime makes the financial markets susceptible to price volatility and performance stress. Today, diverse factors ranging from environmental forces to inherent fundamentals affect the market performance. A well-balanced portfolio may be sufficient to make investors capable of risk reduction. However, many of the risk parameters are systematic in nature and its control ability in financial literature is often questioned. Hence, the investors seek innovative measures to manage their risk and derivatives are one of the prominent tools in the hands of investors to hedge their risk against market failures.

India is one of the leading producers of Rubber in the world. From the very beginning of global meltdown of 2008 , there has been wild fluctuations in the prices of most commodities including rubber traded across the globe. The Financial Crisis caused some distractions and qualms in the future supply and demand for natural rubber that lead to higher rubber price volatility (Goh, Tan, Khor and $\mathrm{Ng}$, 2016). Though, there has been an uptrend in the prices of rubber in general, it has undergone serious price fluctuations over the years which, is more severe than that were prevailing during pre crisis days. Unstable prices of rubber in domestic and global markets put not only the producers, but also the traders and investors in financial distress and their conditions became more vulnerable during later years. Derivatives are found much effective in risk measurement and control (Easwaran and Ramasundaram, 2008). If the markets are frictionless and functioning efficiently, changes in the spot prices of assets and its corresponding future prices would be expected to be perfectly contemporaneously correlated and not to be cross correlated (Brooks, 2012). In the backdrop of this observation, it is very important to examine the hedging effectiveness and optimal hedge ratio of futures contract on rubber to manage the risk of investors and traders from a leading producer country. Consequently, we can verify the effects of financial crisis on the hedging efficiency of Indian rubber Future markets. Hence, this research, comparing the price behaviour of Spot and Future markets during pre-recession and post-recession periods, examines price discovery and hedging efficiency of Indian rubber market. The study of this kind definitely will be a great help to farmers and

Copyright (C) 2018 Saji Thazhungal Govindan Nair

doi: 10.24294/fsj.v1i3.608

EnPress Publisher LLC.This work is licensed under the Creative Commons Attribution-NonCommercial 4.0 International License (CC BY-NC 4.0).

http://creativecommons.org/licenses/ by/4.0/ 
exporters who are potentially interested in gaining access to a hedging vehicle.

The remainder of the paper proceeds as follows. Next section reviews existing studies on price discovery and hedging efficiency of derivative markets that happened in Indian and Global context. A brief sketch of the data and methodology is given in Section 3. Section 4 discusses the results of empirical analysis before concluding the research with its limitations and scope for future research in Section 5.

\section{Literature review}

Commodity Futures' and 'Derivatives' have been well recognised for the functions of risk management and forward pricing for a long time. During 1990s, the economic liberalisation in many countries led to increasing withdrawal of the government's intervention from the agricultural commodity sector, which made the agricultural prices dependent on the domestic and international market forces (UNCTAD, 1997; 1998). Consequently, the need for an efficient price risk management system for the protection of commodity sector from price volatility has been realised seriously (Ali and Gupta, 2011). Commodity futures and derivatives have a crucial role to play in the price risk management process, especially in agriculture (Easwaran and Ramasundaram, 2008). The dependency of commodity market has been in upswing for the last few years, the same is fairly revealing in its growth trend (Massod and Chary, 2016). Shanmugam and Dey (2011) claimed that the commodity market have performed better for all the stakeholders.

Studies examining the hedging efficiency of future contracts have come out in different market context. Loy (2002) analysed the potentials for income risk reduction and income variation for slaughter hog producers in Germany and Holland. The research found significant impact of hedging on income risk and variance and the optimal hedge ratio is smaller for variance compared to risk minimizing hedging strategy. Dharmasena, and Bessler, (2004) studied the efficiency of price discovery process using time series data from seven international black tea markets including India. Results of unit root tests suggested that prices in Indian market are exhibiting random-walk like behaviour, while all non-Indian markets exhibited weak-form efficient as their prices showed random walk behaviour. Gupta and Singh(2007) probed into the evidences for the price discovery and hedging efficiency of NIFTY and all those stock futures during the period 2001-2006. The study observed the presence of information asymmetry in both futures and spot market and found strong long-run relationship between two markets. Their results imply that futures market is an efficient price discovery vehicle for the cash market.

Analyzing spot and future market prices data on six commodities, Iyer and Pillai, (2010), proposed evidence for the differential impact of price convergence during expiration week (relative to non - expiration weeks) for different commodities market in India. For copper, gold and silver, the rate of convergence is almost immediate during the expiration week of the futures contract that confirms the utility of futures contracts as an effective hedging tool. In case of chickpeas, nickel and rubber the convergence degenerate during the expiration week indicating the inefficiency of futures contract for hedging. The findings of Gupta (2011) revealed significant amount of co-integration between futures and spot prices for many agricultural commodities in India. The analysis of short - term causality test indicate that futures markets have stronger ability to predict subsequent spot prices and bi - directional relationships are evident in most cases. For comparing the differences in price discovery and risk transfer functions across different markets, Zhang (2013) analyzed the spot and future markets of two related commodities - crude oil and gasoline. His study identified greater contribution of the futures markets compared with that of the spot markets. Crude oil futures price performs the risk transfer function much better than gasoline futures price in interactions with their respective spot prices. In a similar study conducted on leading energy commodities, crude oil and natural gas, and on gold, the key asset for both investment and hedging during the global financial crisis, Nicolau and Palomba (2015) claimed that interactions between spot and futures prices clearly exist in the selected commodities and they mainly depend on commodity type and contracts maturity. A strong exogeneity operates in the case of the natural gas, while exogeneity generally is weak and depends on the contract maturity for crude oil. On the gold market potentials for price discovery and forecasting are almost absent.

In a perspective study conducted among brokers, Gupta, Chaudhary and Agarwal (2016) found that price discovery 
and hedging effectiveness functions are well performed by all the commodity futures except the energy commodities futures. Energy commodities, being the most volatile commodities, are perceived as having less hedging effectiveness as compared to others. In another research of Gupta, Chaudhary and Agarwal (2017) demonstrated the diverging efficiency of commodity futures in hedging price risks. Their study revealed that futures market provides higher hedging effectiveness in precious metal compared to industrial, metal and energy commodities.

In their study, Goh, Tan, Khor and Ng, 2016 observed that the Price volatility in rubber market pose significant risk to producers, traders, and consumers. The 2008 Global Financial Crisis caused some disruptions and uncertainties in the future supply or demand for natural rubber and thus leading to higher rubber price volatility. Their research, using volatility models, empirically analyzed the dynamics of the price volatility of Standard Malaysia Rubber Grade 20 (SMR 20) in the Malaysian market before and after the Global Financial Crisis. Their results denote the existence of volatility clustering and long memory volatility in the SMR 20 market for both periods and they demonstrated leverage effect in the SMR 20 market where negative innovations (bad news) have a larger impact on the volatility than positive innovations (good news) for post-crisis period. Over post-crisis period, long traders of rubber SMR 20 inclined to unlimited losses with limited gains.

\section{Data and methodology}

\subsection{Data}

The study solely bases on secondary data. Time series data of daily futures and spot prices of Rubber for a period of fourteen years (2004-2017) have been used for the study. For gaining some glimpses on co- variation of Indian rubber price behaviour with international rubber price behaviour we have collected data on international rubber prices also. The research arbitrarily divides the study period into pre-recession period (2004-2008) and post-recession period (2009-17) for gaining useful insights from the findings on objectives specified. We have collected needed data from the web sources of National Multi Commodity Exchange (the leading commodity trader in India) and Rubber Board, Government of India.

\subsection{Methodology}

Descriptive statistics have been computed, at first, for comparing the price trend as well as volatility prevailing in both spot and future markets for rubber in India. OLS (Ordinary Least Square) based co integration test, proposed by Engle and Granger (1987) has been used for computing optimal hedge ratio

Hedge Ratio and Engle Granger's Co-integration Test

The hedge ratio compares the value of a position protected through the use of a hedge with the size of the entire position itself. A hedge ratio may also be a comparison of the value of futures contracts purchased or sold to the value of the cash commodity being hedged. Optimal hedge ratio is the number of future contracts that one should be tailored adequately to cover his risk of holding asset in spot market.

Engle and Granger (1987) introduced a very simple tool for the evidence of co-integration. It is an OLS (ordinary least square) based co-integration test, which has been used for comparing optimal hedge ratio in our analysis. We estimate the co-integration relationship between markets using the following equations.

$\Delta S_{t}=\beta_{1}+\beta_{2} \Delta F_{t}+\ldots .+e_{i}$

$\Delta F_{t}=\beta_{1}+\beta_{2} \Delta S_{t}+\ldots .+e_{i}$

$\Delta S_{t}$ - Price change in spot market price for rubber

$\Delta F_{t}$ - Price change for Future market for rubber

Unlike other co-integration tests, Engle and Granger (1987), in their seminal work, performed their own Monte Carlo simulation in order to construct critical values for co integration tests (Enders, 1995)

\section{Results and Discussion}

\subsection{Descriptive}

Figure 1 shows the rubber price movement during pre recession period of 2004-2008 in Indian spot, future and 
International market. Both international and domestic spot and future prices of rubber are moving in same direction during this period. The prices of rubber in domestic market move in accordance with international rubber prices till 2006 and after that there were some deviations between the international rubber prices and domestic prices in 2006 and 2007. However, in the middle of 2007 the domestic prices moved closely with international price before they showed reverse trend in the year of 2008 .

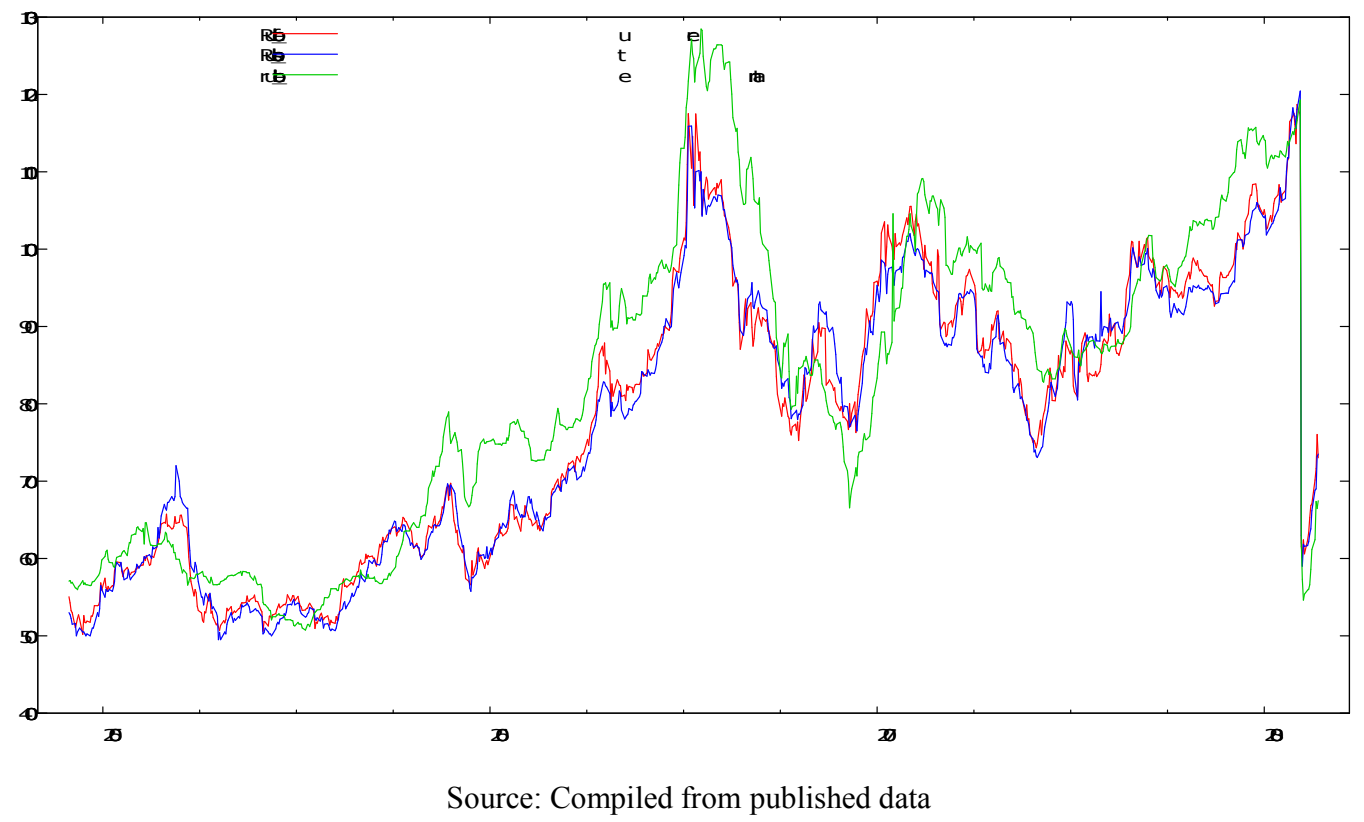

Figure 1; Rubber price movement during pre recession period: spot, future and international market.

During the post recession period the domestic and international market showed wide deviations in rubber prices apart from slight deviations in mid years (Figure 2). The prices of rubber in domestic market moved in accordance with international rubber prices till 2011 and after that the market registered huge fluctuations with international rubber prices. The trend resulted in deviations of international rubber from domestic rubber price from 2016 onwards and the same is persisting in the next year also.

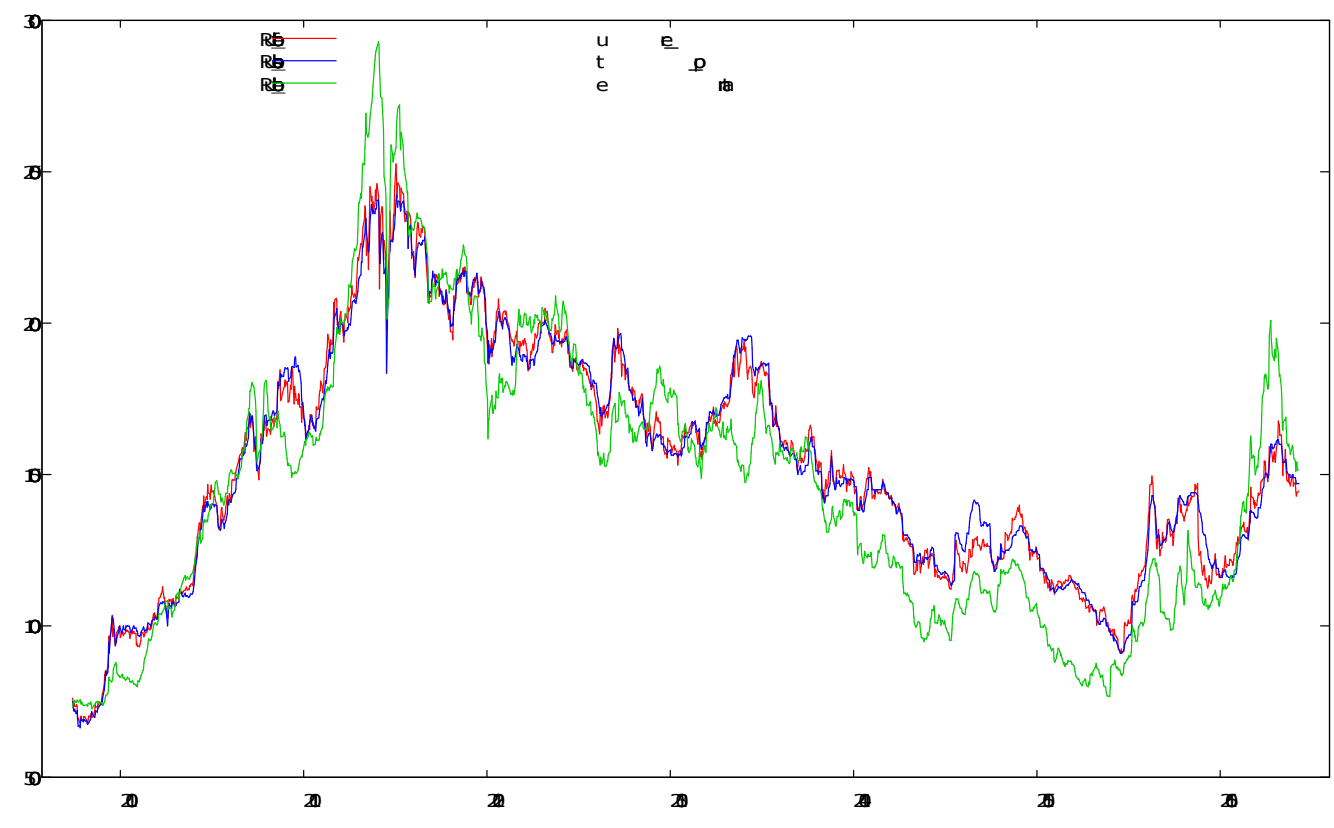

Source: Compiled from published data

Figure 2; Rubber price movement during post-recession period: spot, future and international market.

Source: Compiled from secondary data 
During the pre-recession period, the average prices of rubber in spot and future markets in India were almost equal. Convergence was quite revealing with regard to market volatility also. On observing skewness coefficient, rubber spot prices were almost normal while rubber prices in future market found slightly positively skewed (Table 1).

One could observe momentous changes in price behaviour of both spot and future rubber markets in India during post recession phase (Table 2). The average prices of rubber have almost doubled during this period, while previous trend remained in price volatility in terms of coefficient of variation. None of the markets were strictly normal, despite spot market exhibited more symmetry in distribution of prices.

\begin{tabular}{|l|l|l|l|l|l|}
\hline Variable & Mean & $\begin{array}{l}\text { Standard } \\
\text { Deviation }\end{array}$ & CV & Skewness & Kurtosis \\
\hline Rubber- Future & 7821.29 & 1808.36 & 0.231 & 0.075 & -1.25467 \\
\hline Rubber-Spot & 7778.23 & 1783.81 & 0.229 & 0.016 & -1.23078 \\
\hline
\end{tabular}

Table1. Price movement in spot and future markets during pre-recession period: summary statistics

\begin{tabular}{|l|l|l|l|l|l|}
\hline Variable & Mean & $\begin{array}{l}\text { Standard } \\
\text { deviation }\end{array}$ & CV & Skewness & Kurtosis \\
\hline Rubber- Future & 15326.30 & 3920.92 & 0.255 & 0.189 & -0.607 \\
\hline Rubber-Spot & 15297.00 & 3884.62 & 0.253 & 0.131 & -0.662 \\
\hline
\end{tabular}

Source: Compiled from secondary data

Table 2. Price movement in spot and future markets during post-recession period: summary statistics

\subsection{Hedging Efficiency of Rubber Future Market in India: Co integration results}

The essence of the question raised in this research is to find out and compare the optimal hedge ratios in rubber derivatives market of India during pre and post-recession period. Optimal hedge ratio is the number of future contracts that one should be tailored adequately to cover his risk of holding asset in spot market. OLS (Ordinary Least Square) based co-integration test, proposed by Engle and Granger (1987) has been used for computing and comparing optimal hedge ratio.

If the variables included in the model are integrated at $1(0)$, i.e. the level itself, even a classical regression model can produce robust conclusion regarding the evidence of co-integration (Asteriou and Hall, 2005). When our research performed co-integration methodology suggested by Engle and Granger, we found the integration of Spot and Future market rubber prices at $1(0)$, implying the adequacy of OLS framework in measuring optimal hedge ratio using co-integration technique. The results of co-integration during two distinct periods are reported in Table 3 and 4.

\begin{tabular}{|l|l|l|l|}
\hline Year & B & t-ratio & p-value \\
\hline 2004 & 0.3884 & 4.586 & $0.0000 *$ \\
\hline 2005 & 0.3760 & 7.093 & $0.0000 *$ \\
\hline 2006 & 0.3381 & 7.059 & $0.0000 *$ \\
\hline 2007 & 0.3100 & 5.987 & $0.0000 *$ \\
\hline 2008 & 1.0017 & 44.33 & $0.0000 *$ \\
\hline $2004-2008$ & 0.7504 & 37.78 & $0.0000 *$ \\
\hline
\end{tabular}

Table 3. Optimal hedge ratio for Indian rubber future markets: Pre-recession period

From the results of co-integration test we can see that the rubber market are exposed to lower amount of risk during the pre-recession period. In almost all years in that period, average hedge ratio, that is regression weight of price change in spot contract on a unit price change in rubber futures, is relatively low and is between 0.32 to 0.38 . In fact the size of hedge ratio was declining year after year. Nevertheless, the recession hit year of 2008 has brought in sweeping 
changes in the equilibrium price of rubber. Accordingly the optimal hedge ratio was almost tripled in that year. Before 2008 the risk exposures in rubber spot market was covered by writing futures having value equal to just one third of spot market rubber. However, in 2008 for covering the risk exposure in spot market, one should have contracted equal amount of rubber futures in forward market.

\begin{tabular}{|l|l|l|l|}
\hline Year & B & t-ratio & p-value \\
\hline 2009 & 0.9752 & 124.9 & $0.0000^{*}$ \\
\hline 2010 & 0.9938 & 64.68 & $0.0000^{*}$ \\
\hline 2011 & 0.8794 & 51.05 & $0.0000^{*}$ \\
\hline 2012 & 0.8997 & 45.18 & $0.0000^{*}$ \\
\hline 2013 & 1.1807 & 57.66 & $0.0000^{*}$ \\
\hline 2014 & 0.9030 & 90.85 & $0.0000^{*}$ \\
\hline 2015 & 1.0016 & 27.59 & $0.0000^{*}$ \\
\hline 2016 & 0.9925 & 43.65 & $0.0000^{*}$ \\
\hline 2017 & 0.8491 & 11.64 & $0.0000^{*}$ \\
\hline $2009-2017$ & 0.9855 & 406.5 & $0.0000^{*}$ \\
\hline
\end{tabular}

*Significant at one per cent level

Table 4. Optimal hedge ratio for Indian Rubber Future Markets: Post-recession period

Continue to the trend in 2008, the rubber prices become volatile during post-recession period. However, first three years that is from 2009 to 2011, the hedge ratio slightly has reduced. After that, the next 6 years from 2012 to 2017 the study could not find stability in price change on account of which the hedge ratios continued to fluctuate. In all the years of observation during post-recession phase, the hedge ratio was high indicating almost equal value of future contract is needed to cover the risk exposure in rubber spot market. A close observation of these findings reveals the increased price volatility during the post-recession period have aggravated the traders exposure in forward market which is almost two times more than their exposure during pre-recessionary years.

\section{Conclusion}

The study, covering both pre and post recessionary years, examined the hedging efficiency of Indian rubber market. The efficiency of future markets in hedging price risks of spot markets can be measured from temporal relations between the prices prevailing in two market segments. With the support of Engle Granger Co-integration framework the study confirmed the hedging efficiency of the rubber futures during both pre and post-recession periods. However, increased rubber price volatility after recession have heightened the risk exposures in future market which is almost two times more than their exposure during pre-recessionary years. In sum, well designing of future contracts against current spot contracts enable the investors and traders in domestic rubber market of India to make speculative gains while hedging their risk exposure in spot markets.

Many limitations can be attributed to this study. This research uses relatively simple co-integration technique, Engle Granger model. for predicting long run causality from Future rubber prices to Spot rubber prices, thereby finding the optimal hedge ratio and the prediction of may be subject to estimation errors. For ensuring robustness in results one should use advanced econometric techniques with error correction mechanism. The climate conditions, farming and cultivation pattern as well as the supplies might be different in other country contexts. A study investigating the long run causal relations, with error correction framework, between spot and future prices of rubber from other leading Rubber producing countries can validate the findings on this issue. It is possible and definitely be value line of future research.

\section{References}

1. Ali J and Gupta KB. Efficiency in agricultural commodity markets in India: evidence from co-integration and causality tests. Agricultural Finance Review 2011; 71(2): 162-178.

2. Asteriou D, Hall SG. Applied Econometrics. New York, NY:Palgrave Macmillan, 2005.

3. Brooks C. Introductory Econometrics for Finance. New York, NY: Cambridge University Press, 2008. 
4. Easwaran RS, Ramasundaram P. Whether commodity futures market in agriculture is efficient in price discovery? an econometric analysis. Applied Economics Research Review 2008; 21: 337-344.

5. $\quad$ Enders W. Applied Econometric Time Series, New York: John Wiley, 1995.

6. Engle RF., Granger CWJ. Co-integration and error correction representation, estimation and testing. Econometrica 1987; 55: 391-407.

7. Gupta K, Singh B. Investigating the pricing efficiency of Indian equity futures market. Management and Labour Studies 2007; 32(4): 486-512.

8. Gupta S, Chaudhary H, Agarwal DR. Efficiency of Indian commodity market: A survey of brokers' perception. Journal of Technology Management for Growing Economies 2016; 7(1): 55-71.

9. Gupta S, Chaudhary H, Agarwal DR. Hedging efficiency of Indian commodity futures: An empirical analysis. Paradigm 2017; 21(1): 1-20.

10. Iyer V, Pillai A. Price discovery and convergence in the Indian commodities market. Indian Growth and Development Review 2010; 3(1):53-61.

11. Loy J. Relative forecasting and hedging efficiency of agricultural futures markets in the European Union: Evidence for slaughter hog contracts. Paper Presented at the X Congress of the European Association of Agricultural Economists. Zaragoza, Spain. 28-31 August, 2002.

12. Massod S, Chary TS. Performance of commodities derivatives market in India. Amity Journal of Finance 2016; 1(1):131-148.

13. Nicolau M, Palomba G. Dynamic relationships between spot and future prices. the case of energy and gold commodities. Resources Policy 2015; 45(C): 130-143.

14. Shunmugam V, Dey D. Taking stock of commodity derivatives and their impact on the Indian economy. International Journal of Economics and Management Science 2011; 1(1): 8-16.

15. Goh HH, Tan KL, Khor CY, et al. Volatility and market risk of rubber price malaysia pre and post global financial crisis. Journal of Quantitative Economics 2016; 14(2): 323-344.

16. Zhang YJ. Investigating the price discovery and financial risk transfer function in the crude oil and gasoline future market: Some empirical evidence. Applied Energy 2013; 104: 220-228.

17. Dharmasena S, Bessler D. Weak form efficiency vs semi-strong form efficiency in price discovery: An application to international black tea markets. Sri Lankan Journal of Agricultural Economics 2004; 6(1): 1-24.

18. UNCTAD, (1997). Emerging Commodity Exchanges: From Potential to Success (UNCTAD/ ITCD/COM/4). Available from: http://unctad.org/en/Docs/poitcdcomd4.pdf

19. UNCTAD (1998) A Survey of Commodity Risk Management Instruments (UNCTAD/COM/15/ Rev.2). Available from: unctad.org/en/docs/pocomd15r2.en.pdf 